М.Д. Чемич, Т.І. Фотіна, Г.А. Фотіна, Н.І. Ільїна, С.М. Назаренко, В.В. Ільїна, Л.С. Фролова

\title{
ЕКОЛОГО-БІОЛОГІЧНІ, ЕПІДЕМІОЛОГІЧНІ ТА КЛІНІЧНІ АСПЕКТИ ЕНДЕМІЧНОГО ОСЕРЕДКУ ОПІСТОРХОЗУ В СУМСЬКІЙ ОБЛАСТІ
}

\author{
Сумський державний університет, Сумський національний аграрний університет
}

На території Сумської області зареєстровано 4 види опісторхід: Opisthorchis felineus, Pseudamphistomum truncatum, Metorchis bilis i Metorchis xanthosomus. Встановлено, що осередки опісторхідозів в умовах досліджуваної території прив'язані, в першу чергу, до малих річок. Марити опісторхід у природних екосистемах Сумської області зареєстровані у 5 видів м'ясоїдних ссавців. В антропогенних екосистемах Сумської області провідну роль у циркуляції опісторхід відіграють домашні коти. Проведена оцінка зараження коропових риб метацеркаріями опісторхід. Встановлено, що домінантними з точки зору зараження і накопичення метацеркарій опісторхід є 3 види коропових риб: плітка, краснопірка і уклейка. Опісторхоз переважно перебігає латентно. 3 маніфрестних форм хвороби найчастіше виявляється холецистит (78,6 \%). Вирішальну роль у діагностиці хронічного опісторхозу має копроовоскопія (100 \%). Групу ризику складають рибалки та члени їх сімей $(71,9$ \%). Основним орактором передавання $\epsilon$ солена та в'ялена риба.

Ключові слова: опісторхоз, опісторхіди, короп, молюски бітинії, природний осередок, захворюваність, клініка.

Серед зоонозних гельмінтозів досить широко представлені трематодози, серед яких у даний час найбільш актуальним $є$ опісторхоз. З урахуванням біології розвитку опісторхісів і екологічних особливостей циркуляції опісторхозу - це захворювання визначається, перш за все, як природно-осередковий зоонозний трематодоз [1].

Трематоди родини Opisthorchiidae - порівняно багаточисельна у видовому відношенні група паразитичних червів. У Сумській області зареєстровано 4 види опісторхід: Opisthorchis felineus, Pseudamphistomum truncatum, Metorchis bilis i Metorchis xanthosomus [2-4]. Відомо, що перші два види (O. felineus, P. truncatum) практично однаково патогенні для людини. Види роду
Metorchis також мають епідеміологічне значення [5]. У даному випадку цілком доцільним є об'єднання цих видів у групу збудників «опісторхідозів» $[1,6,7]$. Цим самим підкреслюється, що не можна провести достатньо чітку межу між даними видами як збудниками захворювань.

В даний час опісторхідози широко розповсюджені на території Сумської області (басейн Дніпра). Відмічається часте зараження людей, а також домашніх тварин, перш за все котів [5]. 3 урахуванням наведених даних опісторхідози є актуальною і важливою медичною, ветеринарною й екологічною проблемою. Для вирішення даної проблеми важливо знати екологічну закономірність циркуляції збудників опісторхідозів у конкретних умовах. Вивчення даної проблеми дозволить представити екологію збудників опісторхозу і епізоотичну динаміку цього захворювання в умовах Сумщини.

Мета роботи - дослідити еколого-біологічні особливості циркуляції опісторхозу в умовах басейна Дніпра (річки Псел, Ворскла, Сейм, Сула, Десна) на території Сумської області, з'ясувати параметри епідемічного процесу, провести аналіз захворюваності населення на опісторхоз та визначити основні клініко-діагностичні ознаки недуги.

Сорормульовані такі завдання: дослідити такі закономірності розподілу марит і личинок опісторхід у дефінітивних і проміжних хазяїв (коропових риб); визначити із числа коропових риб види-домінанти, що відіграють важливу роль у накопиченні метацеркарій опісторхід і зараженні десрінітивних хазяїв; дослідити еколого-біологічні особливості і закономірності циркуляції збудників опісторхідозів; показати екологічні передумови і параметри фрормування осередків опісторхідозів; проаналізувати захворюваність на опісторхоз.

\section{Матеріали і методи}

У 2013-2015 рр. методом повного гельмінтологічного розтину [4] досліджено 17 голів хижих тварин (лисиця, куниця кам'яна, куниця лісова, норка американська і до- 
машні м'ясоїдні - собаки і коти). Матеріали для дослідження надані мисливцями, а також отримані при регуляції чисельності безпритульних тварин на території декількох районів Сумської області.

Досліджено близько 300 екземплярів коропових риб 5 видів. Рибу досліджували компресорним методом під мікроскопом МБС-10. Для визначення показників чисельності (індекс зараження) підраховували кількість метацеркарій опісторхід у м'язовій тканині риб. У великої риби (довжиною більше 10 см ) досліджували пробу м'язів масою 2 г. У малих риб повністю досліджували м'язи лівої сторони тіла. В обох випадках у кожної досліджуваної риби проводили абсолютний підрахунок метацеркарій опісторхід.

Таксономічні дослідження матеріалів проводили по визначникам, монографріям та іншим науковим роботам, присвяченим гельмінтам хребетних тварин. Тотальні і тимчасові препарати із личинок і дорослих форм трематоди виготовляли за розробленими і загальноприйнятими методиками $[4,7]$. Діагностичні і мікроморфологічні дослідження личинкових і дорослих форм трематоди проведені на світлових мікроскопах МБС-10, МБИ-6 і Біомед-6, візуалізація досліджуваних гельмінтів - за допомогою вмонтованої цифррової камери.

Для оцінки личинок і дорослих форм опісторхід використовували індекс зараження, інтенсивність і екстенсивність інвазії [1]. Статистичну обробку даних проводили за загальноприйнятими методиками. Для визначення захворюваності населення Сумщини на опісторхоз використовували звітну документацію ДУ «Сумський обласний лабораторний центр Держсанепідслужби України» та медичні картки стаціонарних хворих (ф. 003/о), що перебували на лікуванні в Сумській обласній клінічній інфекційній лікарні ім. 3.Й. Красовицького.

\section{Результати досліджень та їх обговорення}

У даний час на території області зареєстровано 4 види опісторхід: Opisthorchis felineus, Pseudamphistomum truncatum, Metorchis bilis i Metorchis xanthosomus [7], що мають епідеміологічне та епізоотологічне значення [5].

Наявність джерел опісторхозу та їх територіальний розподіл прив'язані до прісних водойм, у першу чергу до малих річок. 3 іншого боку, фрункціональна стійкість джерел обумовлена наявністю необхідних ланцюгів, які прймають участь у життєвому циклі опісторхід: проміжних хазяїв - молюсків-бітиній (перший проміжний хазяїн) і коропових видів риб (другий проміжний хазяїн) і десрінітивних хазяїв. Коропові риби є важливим епідеміологічним і епізоотологічним ланцюгом - джерелом зараження дефінітивних хазяїв, в організмі яких розвиваються дорослі форми (марити) паразита. Останні локалізуються, як правило, в жовчних протоках печінки, у жовчному міхурі, зрідка у підшлунковій залозі. У даний час зареєстровано більше 30 видів десрінітивних хазяїв, включаючи тварин, птахів і людину [1-3, 6, 7].

Результати наших досліджень підтверджують, що опісторхіди мають досить виражені і еволюційно закріплені показники - полігостальність. Ця особливість визначає наявність широкого спектра дефінітивних хазяїв. Марити опісторхід у природних екосистемах Сумської області зареєстровано у 5 видів ссавців, а саме у норки, видри, річкового бобра, лисиці, єнотоподібної собаки.

Серед них ключову роль у циркуляції опісторхід відіграють дикі м'ясоїдні тварини, що мешкають біля води. Встановлено, що зараження норки і видри досягає абсолютних величин. Необхідно відмітити, що у більшості заражених диких тварин у печінці, як правило, виявляли два види опісторхід: O. felineus, P. truncatum.

Цілком примітним $є$ фракт виявлення O. felineus у річкового бобра. Вперше на території Сумської області бобер був зареєстрований в якості нового дефінітивного хазяїна цього паразита. Неординарність цих даних полягає в тому, що бобер вважається винятково рослиноїдною твариною. Як відомо, зараження дефрінітивних хазяїв опісторхідами відбувається тільки при поїданні коропових риб, що мають життєздатних метацеркарій. Можна зробити припущення, що в певні періоди життя (сезони року) бобри можуть харчуватися рибою. За результатами досліджень, на деяких водоймах Сумщини виявлені порівняно високі показники зараження бобрів O. felineus. Так, у системі р. Псел ці показники виявлені на рівні 18,5 \%, що вказує на важливу роль бобра в підтриманні циркуляції опісторхід у природних умовах.

Серед інших тварин-хазяїв певну роль у динаміці опісторхозу в природних осередках може відігравати лисиця. За нашими даними, зараженість ії опісторхідами в природних умовах невелика (11,1\%). Але екологічне значення лисиці в циркуляції цього паразита необхідно пов'язувати з її відносно високою чисельністю на території Сумської області.

В антропогенних екосистемах (населених пунктах поблизу водойм) провідну роль у циркуляції опісторхідозів відіграють домашні тварини і людина. В цих умовах, 3 урахуванням трофічного ланцюга, серед домашніх тварин опісторхідами частіше заражаються домашні коти. Майже в кожній науковій роботі, присвяченій вивченню осередковості і епідеміології опісторхозу, домашня кішка фрігурує як компонент, акумулюючий у своєму організмі «заключні» елементи (марити) опісторхід.

Нами проаналізовано результати лабораторних досліджень за останні 7 років, в яких представлено дані по зараженню котів (54 тварини) маритами опісторхід на різних водоймах у межах Сумської області (мал. 1). 


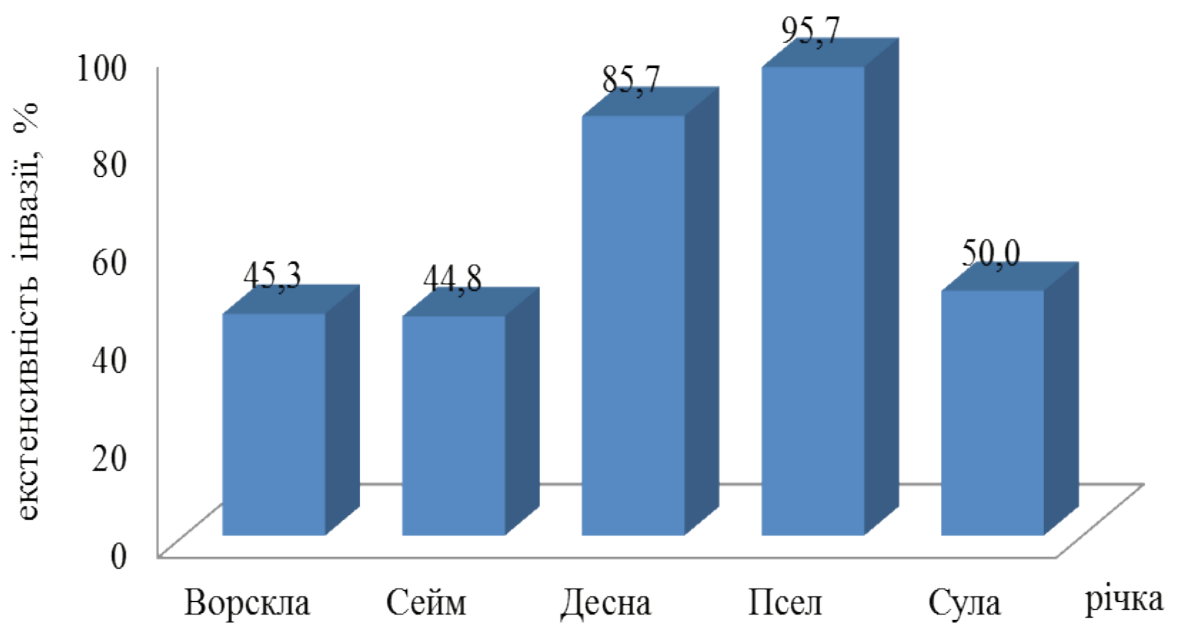

Мал. 1. Зараження котів у населених пунктах поблизу водойм на території Сумської області. Примітка. На гістограмі представлені річки, поблизу яких були зібрані матеріали від котів.

Як правило, досліджували котів із населених пунктів поблизу водойм - малих і середніх річок. Із анамнезу було відомо, що коти постійно харчувалися рибою, виловленою у місцевих водоймах (Ворскла, Сейм, Десна, Псел, Сула). Їх інвазованість маритами опісторхід коливається від 44 до 95,7 \%. Максимальні показники інвазованості котів виявлені на р. Псел і її притоках (мал. 1).

За результатами дослідження, у котів виявлено 3 види опісторхід: P. truncatum, O. felineus, M. bilis. Частіше у котів реєструють $P$. truncatum - 66,7 \%, рідше два інших види: O. felineus і M. bilis - 33,3\%. Інтенсивність інвазії трьома видами опісторхід склала 48,6 екз., у тому числі $P$. truncatum - 29,1 екз., O. felineus - 17,3 і M. bilis $-2,3$.

Встановлено, що коти більш інтенсивно заражені псевдамфістомами, ніж опісторхісами і меторхісами. Тому можна вважати, що в умовах Сумської області інвазійний потенціал псевдамфістомоза вищий, ніж в інших опісторхідозів.

Таким чином, результати досліджень десрінітивних хазяїв доводять, що в природних умовах Сумської області ключову роль в циркуляції опісторхід відіграють дикі хижі тварини, що мешкають поблизу водойм, серед яких домінантом $€$ норка. Але в деяких водоймах басейну Дніпра на території Сумської області суттєве значення в циркуляції цих паразитів має бобер. В антропогенних екосистемах провідну роль у циркуляції опісторхідозів відіграє домашній кіт.

В умовах басейна Дніпра на території області виявлено два види молюсків-бітиній (Bithiidae): Bithynia tentaculata i Codiella inflata, які є першими проміжними хазяями 4 видів опісторхід, зареєстрованих на даній території $[5,7]$.
В умовах малих річок Сумщини зараженість молюсків-бітиній партенитами опісторхід коливається від 2 до 10 \%. На основі попередньо проведених досліджень було встановлено, що бітинії широко розповсюджені й мають високу чисельність у межах акваторії малих річок області [5]. Молюски-бітинії продукують церкарії і $€$ джерелом зараження коропових риб.

Коропові види риб - другий проміжний (додатковий) хазяїн і обов'язкова ланка ланцюга в життєвому циклі опісторхід. У складі коропових риб в якості проміжних хазяїв зареєстровано більше 30 видів [2, 3, 6]. Риба $€$ джерелом зараження опісторхідами дефінітивних хазяїв, у тому числі, в першу чергу, людини. Нами були отримані оригінальні матеріали від коропових риб у природних умовах (р. Ворскла, р. Сула), а також проаналізовані матеріали, що зібрані в різних водоймах області.

За нашими даними [1], в якості другого проміжного хазяїна зареєстровано 9 видів коропових риб: плітка, червоноперка, уклейка, язь, густера, лящ, голавль, лин и подуст. За показниками зараження домінантне місце займають плітка (екстенсивність інвазії 65,7 \%), уклейка $(79,5 \%)$ і язь $(78,9 \%)$, наступний рівень фрормують інші 4 види риб: червоноперка (59,1\%), лящ (51,1 \%), голавль (46,2 \%), густера (40,4 \%), мінімальні показники зараження визначені у линя (33,3 \%) і подуста (16,7 \%). Це характеризує не лише наявність інвазії личинками опісторхід у коропових риб, видове різномаїття інших проміжних хазяїв, а й їх відносну зараженість. Відомо, що динаміка наявності не завжди співпадає з динамікою індекса зараження - чисельності паразита. 3 цією метою ми вивчили індекс зараження [1].

Здійснено підрахунки числа метацеркарій опісторхід у коропових риб. Від кожного екземпляра риб досліджу- 
вали наважку м'язової тканини в кількості 2 г. Аналізу підлягали матеріали від плітки, краснопірки, густери й уклейки. Найбільший показник індекса зараження метацеркаріями опісторхід відмічено в уклейки - 21,6, далі йде червоноперка і плітка, відповідно - 18,0 і 17,6, мінімальні показники зареєстровані у густери - 2,8. Отже, у малих і середніх річках і інших водоймах Сумщини найвищі відносні показники зараження метацеркаріями опісторхід зареєстровані в популяції трьох видів риб: плітки, червоноперки і уклейки. Ці пріоритети зберігаються в даний час, що підтверджує результати наших досліджень. Ми вважаємо, що перераховані три види коропових риб відіграють важливу роль у накопиченні інвазійних елементів і циркуляції паразитарних систем опісторхід. Роль інших видів коропових риб у функціонуванні джерел опісторхідозів менш значна, що обумовлено, в першу чергу, їх відносно невисокою чисельністю. Це підтверджується архівним матеріалом. Ці види як в системах притоків Дніпра, так і в окремих водоймах відіграють важливу роль у накопиченні інвазованих личинок опісторхід [5, 7].

Наведені індекси зараження метацеркаріями опісторхід у трьох видів коропових риб на трьох річках: Ворскла, Псел, Сула. Досить суттєва різниця за рівнями зараження виявлена між водоймами, розміщеними в умовах природних екосистем, і водоймами в антропогенних екосистемах. У Ворсклі та її притоках індекс зараження у фонових видів коропових риб у 1,52 рази нижче, ніж на Десні та Пслі. Це можна пояснити впливом антропогенних фракторів, які обумовлюють більш високу чисельність і концентрацію інвазійних елементів (личинкових стадій розвитку) опісторхід у водоймах.

Отже, на території Сумщини сформувався стійкий ендемічний осередок опісторхозу, що обумовлено як природними, так і соціальними фракторами: поширення любительської риболовлі, значна питома частка риби у харчовому раціоні населення, звичка вживання в їжу сирої або слабо посоленої риби. Проведені дослідження стосовно біології розвитку опісторхід, екологічних особливостей їх циркуляції, інвазованості проміжних хазяїв свідчать про високий ризик зараження людини вже у ранньому віці.

Епідемічна ситуація з опісторхозу в області складна. Кількість хворих, виявлених за останні 5 років, складає 64 \% від загальної кількості в Україні. Захворюваність на опісторхоз у Сумській області у 22-25,6 разу перевищує середні показники в Україні. Спостерігається щорічне підвищення захворюваності з 6,9 на 100 тис. населення у 2000 р. до 22 на 100 тис. у 2015 р. (в Україні 0,67 на 100 тис. населення) (мал. 2).

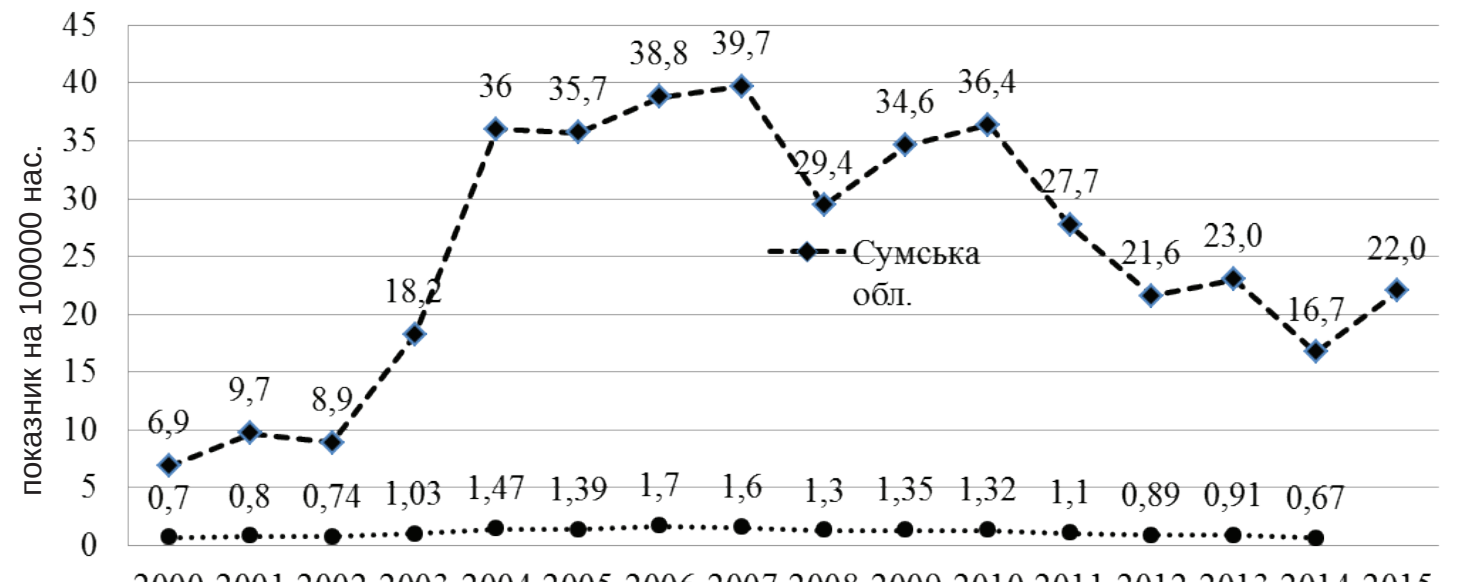

2000200120022003200420052006200720082009201020112012201320142015 рік

Мал. 2. Показник захворюваності на опісторхоз у 2000-2015 рр.

Опісторхоз зареєстрований у 117 населених пунктах області, з них у 14 інвазованість населення перевищує 3 \%. На обліку в медичних закладах знаходиться 1629 хворих, з них 93 \% проживають у м. Шостка та 7 районах області: Буринському, В.-Писарівському, Кролевецькому, Недригайлівському, Роменському, С.-Будському та Шосткінському. Рівень захворюваності населення в цих районах у 4-7 разів перевищує середньообласний і наближається до найбільш інтенсивних осередків Західного Сибіру.

Однак ця статистика відображає лише частину дійсної захворюваності на опісторхоз. Поліморфізм клінічних проявів призводить до того, що хворі звертаються до лікарів інших спеціальностей і часто хвороба залишається нерозпізнаною внаслідок недостатнього знання лікарями цієї патології. 
Серед хворих, які лікувалися з приводу опісторхозу в Сумській обласній клінічній інсрекційній лікарні за період дослідження, переважали жінки (62,5 \%). Середній вік інвазованих склав $(37,09 \pm 1,44)$ років: вікова група до 18 років - 11,6 \%, 19-26 - 23,2 \%, 30-40 - 18,8 \%, старше 40 років - 46,4 \% осіб.

3 географрічного анамнезу з'ясовано, що основний відсоток пацієнтів склали жителі м. Сум та С.-Будського району - 47,3 та 21,4 \% відповідно.

Харчовий анамнез: у 59,8 \% хворих срактором передачі була в'ялена або солена риба. Зараженню опісторхісами сприяли традиційні звичаї у людей, що мешкають поблизу водоймищ, вживати в їжу сиру рибу. Такі харчові традиції є частиною глибоко укоріненої культури і тому важко піддаються змінам. Група ризику (рибалки та члени їх сімей) склала 71,9 \%.

3 клінічних фрорм переважав хронічний опісторхоз. Жодного випадку гострого опісторхозу, який для корінного населення осередку є винятковістю, за період спостереження виявлено не було.

Клініка хронічного опісторхозу зумовлена ураженням біліарного тракту, підшлункової залози та реактивними змінами з боку сусідніх органів.

Аналіз результатів дослідження дозволив виділити ряд синдромів, які спостерігалися 3 різною частотою: холангіохолецистит, дискінезії жовчовивідних шляхів,

Опісторхіси в дуоденальному вмісті Нудота Субфебрилітет Субіктеричність склер Гіркота у роті Біль в епігастрії Гастродуоденіт Астеновегетативний синдром

IФA (+)

Важкість у правому підребер'ї Вживання в'яленої та соленої річкової риби Гастрит Група ризику (рибалки та члени родини)

Гепатомегалія

Ознаки холецеститу Опісторхіси в калі$$
0
$$

гастроінтестинальні прояви, алергічний, панкреатопатія, вегето-судинна дистонія.

У більшості пацієнтів захворювання мало латентний перебіг. Про це свідчить випадкове виявлення яєць опісторхісів у випорожненнях при обстеженні декретованої групи населення (58,2 \%), при зверненні за медичною допомогою з приводу інших захворювань $(17,7 \%)$ і тільки 24,1 \% хворих мали ознаки маніфестації хвороби. Основними клінічними проявами недуги були диспепсичний і больовий синдроми: 56,3 \% хворих скаржилися на почуття важкості в правому підребер'ї, $30,4 \%$ - на біль у епігастрії, 26,8 \% - на гіркоту в роті, 24,1 \% - на нудоту, $17 \%$ - на здуття живота, 10,7 \% - на нестійкі випорожнення, на зниження апетиту $-11,6 \%$, на сухість у роті - 8,9 \%, блювання - 3,6 \%. Не було скарг у 14,3 \% осіб. У більшості хворих визначалась мінімальна інтенсивність інвазії.

Визначаючи діагностичну значущість клініко-лабораторних симптомів у хворих на опісторхоз, встановлено, що найбільше діагностичне значення серед клінічних даних мають ознаки холециститу, гастриту, гепатомегалія, відчуття важкості в епігастрії; із лабораторних - виявлення опісторхісів у калі; з епідеміологічних - належність до групи ризику і вживання термічно необробленої риби (мал. 3).

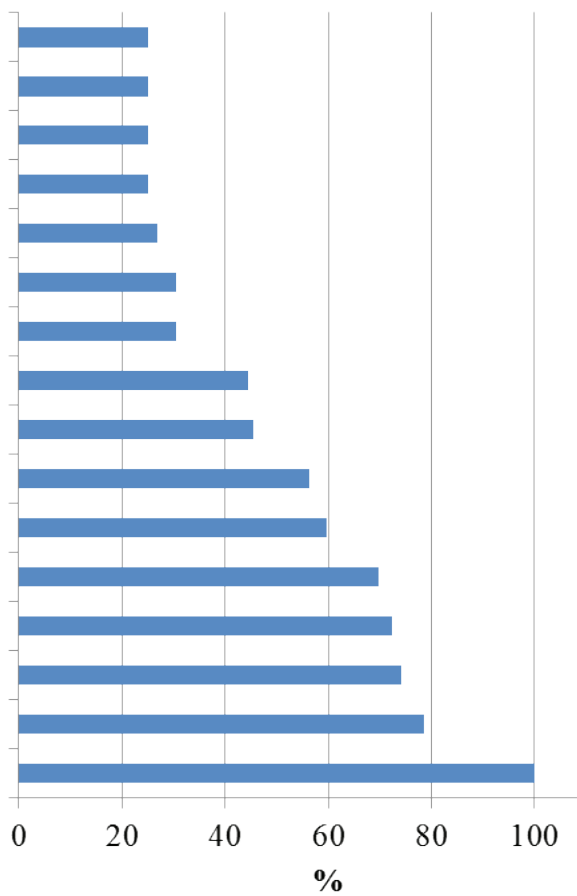

Мал. 3. Діагностична значущість клініко-лабораторних симптомів у хворих на опісторхоз.

Хвороба суттєво впливає на здоров'я населення, спричиняє високий відсоток хронізації, розвиток жовчно- кам'яної хвороби та раку печінки, що зумовлює соціальну і медичну значущість цієї інвазії. 


\section{Висновки}

1. За результатами оригінальних досліджень і на основі даних літератури нами вивчені еколого-біологічні особливості циркуляції трематодозів у природних осередках на території Сумської області. У складі цих гельмінтозів домінуюче значення займає опісторхоз (опісторхідози).

2. Другим проміжним хазяїном опісторхід у басейні Дніпра на території Сумської області $€ 9$ видів коропових риб: плітка, червоноперка, уклейка, язь, густера, лящ, голавль, линь і подуст. Провідну роль у накопиченні і циркуляції метацеркарій опісторхід на досліджуваних територіях мають три види коропових риб: плітка, уклейка і червоноперка.

3. Марити опісторхід на території Сумської області в природних екосистемах зареєстровані у 5 видів тварин: норки, видри, річкового бобра, лисиць і єнотоподібних собак; серед них ключова роль належить диким хижим тваринам, що мешкають біля води. В антропогенних екосистемах важливу роль у циркуляції опісторхідів відіграють домашні тварини, переважно коти, і людина.

4. На Сумщині джерела опісторхідозів прив'язані до систем приток Псла, Десни і Ворскли. У даний час 3 урахуванням специсіки екологічних умов на території області домінують антропогенні джерела цього трематодозу.

5. У Сумській області сорормувався стійкий ендемічний осередок опісторхозу, захворюваність населення на цю недугу у 22-25,6 разу перевищує показники в Україні.

6. Недуга переважно має латентний перебіг. 3 маніфестних фрорм хвороби найчастіше виявляється холецистит (78,6 \%). Вирішальну роль у діагностиці хронічного опісторхозу має копроовоскопія (100 \%). Групу ризику складають рибалки та члени їх сімей (71,9%). Основним фрактором передавання є солена та в'ялена риба.

\section{Література}

1. Паразитологія та інвазійні хвороби тварин / В.Ф. Галат, А.В. Березовський, Н.М. Сорока, М.П. Прус. - Київ: Урожай, 2009. - 368 c.

2. Власенко В.В. Хвороби риб / В.В. Власенко, Ю.Д. Темніханов. - Вінниця, 2012. - 676 с.
3. Грищенко Л.И. Болезни рыб и основы рыбоводства / Л.И. Грищенко, М.Ш. Акбаев, Г.В. Васильков. - М.: Колос, 1999. - 456 с.

4. Зон Г.А. Патологічна анатомія паразитарних хвороб тварин / Г.А. Зон. - Суми: Джерело, 2005 - 226 с.

5. Ситуація з опісторхозу в Сумській області та в Україні / [С.Є. Шолохова, А.О. Сніцарь, В.Б. Міроненко та ін.] // Сучасні інфекції. - 2004. - № 4. - С. 9-11.

6. Давыдов О.Н. Болезни пресноводных рыб / О.Н. Давыдов, Ю.Д. Темниханов. - К.: «Ветинфрорм», 2003. - 544 с.

7. Дахно І.С. Екологічна гельмінтологія / І.С. Дахно, Ю.І. Дахно. - Суми, 2010. - 220 с.

\section{ECOLOGICAL AND BIOLOGICAL, EPIDEMIOLOGICAL AND CLINICAL ASPECTS ENDEMIC FOCI OPISTHORCHIASIS IN SUMY REGION}

M.D. Chemych, T.I. Fotina, H.A. Fotina, N.I. Ilyina, S.M. Nazarenko, V.V. Ilyina, L.S. Frolova

SUMMARY. In the Sumy region recorded 4 species opistorhid: Opisthorchis felineus, Pseudamphistomum truncatum, Metorchis bilis i Metorchis xanthosomus. Established that cell opistorhidoziv in terms of the study area are linked primarily to small rivers. Marit opistorhid in natural ecosystems Sumy region recorded 5 species of carnivorous mammals. In Sumy region anthropogenic ecosystems leading role in the circulation opistorhid play house cats. The assessment of infection carp fish metatserkariyamy opistorhid. Established that dominant in terms of infection and accumulation metatserkariy opistorhid are 3 types of fish, carp, roach, bleak and scardinius. Opisthorchiasis runs mostly latent. On the manifest forms of the disease is often cholecystitis (78.6\%). 3 маніреестних фрорм хвороби найчастіше виявляється холецистит (78,6 \%). A key role in the diagnosis of chronic opisthorchiasis has koproovoskopiya (100\%). Risk groups constitute fishermen and their families (71.9\%). The main factor of transmission is salted and dried fish.

Key words: opisthorchiasis, opistorhidy, carp, clams bityniyi, natural cell, morbidity, clinic.

Отримано 4.05.2016 р. 